\title{
Performance of the Budget of the Regional Representative Council of Tanjungpinang City, Riau Island Province
}

\author{
Muhammad Arif ${ }^{1}$, Endang Larasati ${ }^{2}$, Sri Suwitri ${ }^{3}$ \\ ${ }^{1}$ Student of Public Administration Doctoral Program, Diponegoro University, Indonesia \\ ${ }^{2,3}$ Diponegoro University, Indonesia \\ Email: muhammadarif05031976@yahoo.com
}

\begin{abstract}
The shift of paradigm in the government system that prioritizes the application of the principles of good governance has also been implemented in Indonesia through Government Regulation No. 68/2010. One of the tasks of the legislature in order to increase the value of government effectiveness is the function of checks and balances. If this function is carried out properly by the legislature, then at least it can increase the effectiveness of the Indonesian government. In relation to budgeting, the budgeting process starts from the discussion of the General APBD Policy (KUA), discussion of the APBD draft submitted by the regional head, to the implementation and accountability of Regional Regulations concerning the APBD. In the context of good governance, the participation of the DPRD must be realized in every process of preparing the APBD by upholding fiduciary duties. The universal principles of good governance are very precisely applied in realizing the budgeting function. In the context of good governance, the participation of the DPRD must be realized in every process of preparing the APBD by upholding fiduciary duties. The universal principles of good governance are very precisely applied in realizing the budgeting function.
\end{abstract}

Keywords: Budget Performance, Development, Regional Representative Council.

\section{A. INTRODUCTION}

The shift of paradigm in the government system that prioritizes the application of the principles of good governance has also been implemented in Indonesia through Government Regulation No. 68/2010. The regulation states that good governance basically requires the involvement of all stakeholder components, both within the bureaucracy. as well as in the community. The World Bank measures governance indicators in 212 countries based on approximately 40 data sources produced by more than 30 organizations spread throughout the world. The World Bank's corrupt practices in Indonesia reached a nadir (worst score of 7.3) in 2002, but the trend - albeit slowly - continues to rise, making it into the second lower quartile zone (score 27.1) in 2007.

In the context of the effectiveness of the government, the responsibility does not all fall on the executive branch. In practice, the effectiveness of the government can lead to an analysis of the relationship between the executive and the legislature. This is because the duties and responsibilities of the executive branch must be balanced with the duties and responsibilities of the legislature.

One of the tasks of the legislature in order to increase the value of government effectiveness is the function of checks and balances. If this function is carried out 
properly by the legislature, then at least it can increase the effectiveness of the Indonesian government.

The Riau Archipelago Province was one of the provinces that were partitioned in 2002. As a new autonomous region, the functions of government administration in the Riau Islands Province have not been fully maximized. This includes the performance of the DPRD, especially in carrying out the budget function.

The budgeting function is the most crucial thing in relation to government administration. With the budgeting function, the budget will be determined for the current year. The DPRD of Tanjungpinang City has quite a tough task in carrying out its duties in order to make the administration of government in Tanjungpinang City effective.

Political map in Tanjungpinang City, the Indonesian Democratic Party of Struggle (PDI-P) dominates the number of seats in the DPRD. Of the 30 seats, PDI-P won 7 seats for the 2014 - 2019 period. PDI-P dominance continued when the Chair of the PDI Branch Leadership Council -P Tanjungpinang City, Suparno, was reappointed as chairman of the DPRD. The Golkar and Hanura parties are the parties with the second highest number of seats, with 4 seats each.

As for the development of Tanjungpinang City, the increase in the budget is indicated by the development efforts carried out by the Tanjungpinang City Government. This requires a large amount of money. For example, roads which are a means of supporting transportation still need to be repaired.

In relation to budgeting, the budgeting process starts from the discussion of the General APBD Policy (KUA), discussion of the APBD draft submitted by the regional head, to the implementation and accountability of Regional Regulations concerning the APBD. In the context of good governance, the participation of the DPRD must be realized in every process of preparing the APBD by upholding fiduciary duties. The universal principles of good governance are very precisely applied in realizing the budgeting function.

Good governance in this budgeting function can play a more role if it gets attention and accuracy in the preparation of KUA (among others (1) the effectiveness of the formation of love networks, (2) elimination of individual, group and group interests, (3) reforming the preparation of RPJMD and Renstra-SKPD, and (4) capacity building of DPRD in formulating KUA) and preparation of PPAS (among others (1) accountability for budget value, (2) completeness of supporting data, (3) capacity building for DPRD members and regional governments in setting priority functions and functions. program, and (4) compatibility between program priorities and community needs). The existence of an explanation of the ideal implementation that should be carried out by the DPRD of Tanjungpinang City and the existing conditions that occur is an interesting thing to study.

This is related to the ideal conditions of performance management and the existing conditions of the performance model of the Tanjungpinang City DPRD. With the current performance model (budgeting is more concerned with non- 
community groups, less careful review of related documents, less accommodated people's aspirations, it requires the need for an ideal performance model (upholding the principles of good governance) in the implementation of the budgeting function in the City DPRD) Tanjung Pinang.

\section{B. DISCUSSION}

Regional Original Income (PAD) as a source of regional revenue has a very strategic position towards regional independence in the field of financing. In the PAD component, it is reflected in the ability of the region to self-finance the running of its government. Development of Tanjungpinang City Regional revenue in relation to Regional Original Income (PAD), is directly and indirectly an indicator of SKPD performance in exploring sources of income from year to year.

The development of the amount of PAD in contributing to the APBD is one of the benchmarks for assessing the ability and level of independence of a region in implementing regional autonomy. This level of independence can also be seen as an indicator for local governments whether the implemented strategy is able to answer all the problems it faces.

Regional expenditure is structured to finance the implementation of regional government affairs which fall under the authority of the provincial government and district / city governments, which consist of mandatory and optional affairs. The arrangement of expenditures for the implementation of the said obligatory functions is based on the stipulated Minimum Service Standards (SPM).

For this 2018 fiscal year, the draft regional expenditure plan is Rp. $790,734,988,319$ which decreased the target of Rp. 130,765,011,681 (14.19\%) of the total expenditure in the 2017 APBD fiscal year, namely Rp. 921,500,000,000 This decrease was due to a decrease in the Balancing Fund sector, Other Legal Regional Revenues and a decrease in the target for the Previous Year's Budget Calculation Excess (SiLPA), which actually shows that the SKPD's performance is getting better in realizing the programs and activities contained in the SKPD Budget Implementation Documents (DPA).

The policy for Indirect Expenditures for fiscal year 2018 is planned at Rp. $367,169,303,054$ While the direct expenditure policy is Rp. 423,538,685,265. The personnel expenditure policy in question constitutes compensation in the form of salaries and allowances as well as other income provided to civil servants which are stipulated in accordance with statutory provisions.

In addition, local governments can also provide additional income to civil servants based on objective considerations by taking into account the regional financial capacity. Employee expenditure needs by anticipating regular salary increases, family allowances, transfers and additions to PNSD, acress is calculated, the amount of which is limited to a maximum of $2.5 \%$ of total employee expenditure (salaries and allowances). In addition, it has also taken into account the provision of salaries for the 13th and 14th months. Employee spending at the Indirect Shopping post (BTL) for the 2018 fiscal year is Rp. 336,625,994,754 
When viewed from the consistency of the relationship between KUA, PPAS and RAPBD with RKPD and RPJMD. One of the Banggar members stated that this was something that could not be separated, meaning that there had to be a close relationship between the KUA, PPAS and RAPBD with the RKPD and RPJMD, but in fact the RKPD and RPJMD were not used as the basis for preparing the KUA, PPAS and RAPBD.

Meanwhile, the Chairman of the Political and Political Institution, Raja Ali Haji Tanjungpinang stated that the document contained more interests of the DPRD and the executive rather than the interests of the community, furthermore the translation of the RPJMD to the RKPD was less able to detail them into program activities.

To ensure consistency and acceleration of the discussion of the KUA draft and the PPAS draft, the Mayor must submit the KUA draft and the PPAS draft to the DPRD at the same time, after which the results of the discussion of the two documents are mutually agreed upon by the Mayor and DPRD at the same time, so that the substance of the KUA is integrated. and PPAS in the process of drafting the RAPBD will be more effective. According to one member of the Banggar, the obstacles faced by the DPRD in carrying out its budget functions are because each member of the council is concerned only with the interests of the aspirations of the council itself and its political interests.

In every process of planning and preparation of the APBD, it refers to PP. 58 of 2005 concerning Regional Financial Management. In the PP, the planning and preparation of the APBD outlines 5 (five) processes that have been followed, namely (a) preparation of local government work plans (RKPD), (b) preparation of general APBD policy drafts and provisional budget priorities and ceilings, (c) preparation of SKPD work plans and budgets, (d) drafting local regional budgets, and (e) determining APBD. Referring to the regulations, the involvement of the Tanjungpinang City DPRD in the planning and preparation of the APBD is directly seen in 3 (three) processes, namely points $b, d$, and e.

The planning and preparation of the APBD begins at the regional government and SKPD levels within the Tanjungpinang City Government. This relates to the implementation of the first process, namely the preparation of a local government work plan. This process begins with SKPD compiling a strategic plan (RenstraSKPD) which contains vision, mission, objectives, strategies, policies, programs and development activities that are indicative in accordance with their respective duties and functions. The preparation of the intended SKPD Renstra is guided by the regional medium-term development plan (RPJMD). The RPJMD contains the direction of regional financial policies, regional development strategies, general policies, and SKPD programs, across SKPDs, and regional programs.

After a Memorandum of Understanding is issued, the Budget Team (TAPD) prepares a regional head circular regarding the Guidelines for the Preparation of RKA-SKPD which must be issued no later than the beginning of August of the current budget year. Arrangements in the planning aspect are directed so that the 
entire APBD preparation process can show the background of decision making in determining general policy direction, priority scale and determining the allocation and distribution of resources by involving community participation. Meanwhile, budget preparation is carried out using three approaches, namely the medium-term expenditure framework (MTEF) approach, the integrated budgeting approach, and the performance budgeting approach.

Meanwhile, with regard to the level of public satisfaction with the DPRD's performance in carrying out its budgeting function, some informants stated that they were not satisfied. Furthermore, it was stated by one of the informants that this satisfaction could not be measured because there were no clear parameters to measure it. besides the performance results in this budgeting function cannot be seen in a transparent manner.

The use of performance indicators is very important to determine whether an activity or program has been carried out efficiently and effectively. Basically, there are 2 (two) things that can be used as performance indicators, namely budget performance (budget policy) and performance budget.

Budget performance is a tool or instrument used by DPRD to evaluate the performance of the Regional Head. These tools are in the form of macro strategies and policies contained in the Propeda and Renstrada, the direction and general policies of the APBD, as well as the strategies and priorities of the APBD. The financial budget is a tool or instrument used by the regional head to evaluate work units under the control of the regional head as the chief executive.

The mechanism for formulating APBD strategies and priorities can be carried out by the DPRD to make efforts to gather community aspirations and formulate the main ideas of the council. Subsequently, various communications and agreements were held in the form of APBD direction and general policies. The direction and general policy of the APBD is basically an annual plan that is part of the medium-long-term plan and the long-term plan contained in the strategic plan or other planning document. The local government and the DPRD use the strategic plan or other planning documents as the basis for preparing the APBD.

The APBD implementation stage is carried out by using an adjusted accounting system to produce recording documentation as a report on the implementation of the APBD by the executive, either in the form of a quarterly report or an annual report as a regional head's accountability report to the DPRD. This information is open in nature, and can be used by the DPRD as a means of controlling regional financial allocations and checking the appropriateness of allocations with plans. In the control / supervision stage, various reports (as input) for the implementation of the APBD are processed by evaluating the report, which can also be used as an assessment of the accountability of the regional head. DPRD can use this financial report as an indicator to accept or reject the regional head's accountability report. 
The new paradigm of local government administration demands public accountability. Public accountability in terms of regional finance here is the obligation of the Regional Government to provide accountability, present, report, and disclose all activities and activities related to the receipt and use of public money to parties who have the right and authority to hold this accountable (DPRD and the wider community) In connection with the demand for accountability, the DPRD has a bigger role and authority than in previous times.

\section{CONCLUSION}

The use of performance indicators is very important to determine whether an activity or program has been carried out efficiently and effectively. Basically, there are 2 (two) things that can be used as performance indicators, namely budget performance (budget policy) and performance budget (performance budget). Budget performance is a tool or instrument used by DPRD to evaluate the performance of the Regional Head.

The implementation of SAB will basically provide benefits, including (1) encouraging each work unit to be more selective in planning its programs and/or activities, (2) avoiding ineffective spending in efforts to achieve performance, (3) reducing overlapping spending in investment activities. and non investment.

The formulation of general APBD direction and policies generally uses a number of assumptions and to achieve them, various problems, constraints and challenges are often encountered due to limited resources. In this case, a certain strategy or method is needed which is expected to facilitate or accelerate the achievement of the general APBD direction and policies. Priorities are needed because of limited resources to achieve the direction and general policy of the APBD.

In governance, the government (together with the DPRD) issues various policy products to fulfill its obligations to society. One of these regional policies is in the form of the Regional Revenue and Expenditure Budget (APBD) which is a social contract from the government to allocate funds to finance activities according to the priority needs and problems of the community.

APBD here is a social contract between the government and the community, where the government "promises" to finance various activities that have been planned to meet various demands and resolve various problems that exist in society.

With PP 105/2000 (followed up by Kependegari No. 29/2002, as well as promulgated by Law No. 17 of 2003 on State Finance), a performance budgeting system has been established which puts forward work performance as measured by indicators. outputs, results, benefits and impacts so that considerations of benefit to the community are of great concern. 
In its implementation, the budget system can face various obstacles, such as the unpreparedness of the community, DPRD and government to implement Performance budgeting, including the unpreparedness of the central government in facilitating the development of a performance-based budgeting system as well as a timetable that is not accommodating to other sub-systems (linkage of the national budget to the APBD).

\section{REFERENCES}

1. Wahab, S. A. (2002). Analysis of Wisdom, From Formulation to Implementation of State Policy. Jakarta: Bumi Aksara.

2. Anderson, B. (2009). The Changing Role of Parliament in The Budget Process. OECD Journal on Budgeting, 9(1), 37-47.

3. Anderson, J. E. (2006). Public Policy Making: An Introduction. Boston: Houghton Mifflin Company.

4. Arif, M. (2013). Performance of the Regional Representative Council of the City of Tanjungpinang in the Implementation of Budgeting, Supervision and Legislation Functions. (Thesis Open University).

5. Arniati, Imelda, \& Kartikaningdyah, E. (2010). The Influence of Human Resource Capacity, Political Budgeting, Planning and Supporting Information on Synchronizing APBD Documents with KUA-PPAS Documents in the Government of Tanjungpinang City. XIII National Accounting Symposium in Purwokerto.

6. Bach, T. (2012). The Involvement of Agency in Policy Formulation. Policy and Society, 31, 211-222.

7. Tanjungpinang City Central Statistics Agency. (2015). Tanjungpinang in Figures 2015. Tanjungpinang: BPS Tanjungpinang City.

8. Barber, G. (1986). Correlates of Job Satisfaction among Human Services Workers. Administration in Social Work, 10(1), 25-38.

9. Barzelay, M. (1992). Breaking Through Bureaucracy: A New Vision For Managing Government. Berkeley, California; University of California Press.

10. Behery, M., Jabeen, F., Parakandi, M. (2014). Adopting A Contemporary Performance Management System: A Fast-Growth Small-to-Medium Enterprise (FGSME) in the UAE. International Journal of Productivity and Performance Management, 63(1), 22-43.

11. Borzel, T. A. (1998) Organizing Babylon on the Different Conceptions of Policy Networks. Public Administration, 76, 253-73.

12. Bozeman, B., \& Strausman, J. D. (1990). New Public Management Strategies: Guideline for Management Strategies. Jossey Bass, San Francisco. 